\title{
10-Й ВСЕМИРНЫЙ КОНГРЕСС ПО ПЕРИНАТАЛЬНОЙ МЕДИЦИНЕ
}

\section{Ю.В. ДАВЫДОВА \\ д.мед.н., заведующая отделением акушерских проблем экстрагенитальной патологии Института педиатрии, акушерства и гинекологии НАМН Украинь}

В городе Пунта дель Эсте (Уругвай) с 8 по 11 ноября 2011 г. проходил 10-й Всемирный конгресс по перинатальной медицине с участием ведущих специалистов из 190 стран. На нем был представлен 461 результат научных изысканий в виде устных и постерных докладов. В работе этого конгресса принимала участие д.мед.н., заведующая отделением акушерских проблем экстрагенитальной патологии Института педиатрии, акушерства и гинекологии НАМН Украины Ю.В. Давыдова.

Следует отдельно остановиться на том факте, что Уругвай является страной, из которой началась фрундаментальная новаторская работа по перинатологии, что и стало девизом конгресса. В 1947 г. в Монтевидео профрессор Роберто Калдейро Барсия (Roberto Caldeyro Barcia) впервые осуществил запись маточных сокращений. Впоследствии маточную активность стали измерять в единицах Монтевидео.

Как следует из всех заседаний конгресса и ключевых лекций, очевидным становится то, что сегодня перинатология объединяет достижения различных отраслей медицины: акушерства, неонатологии, генетики, психологии, социологии, хирургии. Все они служат человечеству - беременным женщинам и матерям, которым мы можем помочь сегодня и сейчас, а также новорожденным, которым потребуются наши усилия в будущем.

Научная программа включала все аспекты современной перинатологии. Особое внимание уделялось проблемам минимизации последствий преждевременных родов, ранней диагностики и выбора оптимальной тактики ведения беременности и родов при преэклампсии; вопросам психологии, послеродовой депрессии; профилактике и оптимизации тактики при послеродовых кровотечениях; усовершенствованию методики респираторной поддержки глубоко недоношенных детей, тактике при послеродовых свищах; отдаленным последствиям глубокой недоношенности; оптимизации ведения беременности и родов при многоплодной беременности.

Отдельная сессия была посвящена фетальной хирургии, в том числе оперативному лечению транспозиции магистральных сосудов, гипоплазии левых отделов сердца (професcop Джек Райчик [Jack Rychik], США), стратегии EXIT (технология EXIT - «вне матки, частично внутри». Во время кесарева сечения извлекают лишь головку и одну ручку плода - прим. ред.) при гигантских опухолях шеи у плода (профрессор Пабло Лайе [Pablo Laie], Apгентина), обоснованию и определению времени и места оперативного вмешательства для выполнения внутриутробного хирургического вмешательства (профрессор Йон Хаетт [Jon Haett], Австралия). Каждый из докладчиков останавливался на алгоритме разработки модели оперативного вмешательства, отработки юридических и этических аспектов при проведении оперативного вмешательства и последующего родоразрешения.

Профрессор С. Арулкумаран (S. Arulkumaran, Великобритания) посвятил свои лекции проблемам снижения материнской смертности во всем мире с учетом необходимости достижения Целей развития тысячелетия, а также тактике HAEMOSTASIS (Help - вызов помощи; Asses and resuscitate - оценка состояния и реанимационные мероприятия; Establish Etiology, Ecbolics, Ensure availability of blood - этиология, утеротонические средства, препараты крови; Massage uterus массаж матки; Shift to theater - перевод в операционную; Tamponade - тампонада полости матки; Apply sutures - наложение компрессионных швов; Systematic pelvic devascularisation - перевязка сосудов; Interventional radiologist - эмболизация маточных сосудов, под контролем лучевых методов визуализации (по возможности); Subtotal or total abdominal hysterectomy - экстирпация или надвлагалищная ампутация матки - прим. ред.) при профилактике и лечении послеродовых кровотечений.

Профрессор Роберто Ромеро (Roberto Romero, США) в своих выступлениях коснулся достижений последних лет в выявлении причин преждевременных родов, поиске скрининговых методик и диагностических критериев с целью определения пациенток группы риска по развитию преждевременных родов, с тем чтобы именно в этой группе проводить активные лечебные мероприятия, в том числе манипуляции в виде наложения пессария Арабин, серкляж-модификации Широдкара. 
Также были представлены данные об эффрективности применения системы Odon для оптимизации ведения второго периода родов, что является более щадящей манипуляцией для матери и плода, менее травматичной для родового канала.

Значительное внимание было уделено профилактике реализации внутриутробного инфицирования, в том числе диагностике активации хориоамнионита инвазивной методикой при решении вопроса о целесообразности наложения пессария Арабин или применении серкляж-модификации Широдкара.

Президент Всемирной ассоциации перинатальной медицины Франк Червенак (F. Chervenak, США) в своем выступлении отметил, что сегодня, в 21-м нии профессор Дан Фарине (Dan Farine, Канада) огласил данные об эффрективности применения скрининговой программы CALM в прогнозировании дистоции плечиков и вследствие этого уменьшение последствий родового травматизма.

Результаты исследований, представленные на этом конгрессе, основные направления научных изысканий, провозглашенные ведущими перинатологами мира, позволят координировать научнопрактическую работу в нашей стране в области перинатологии, особенно сейчас, когда в Украине проводится программа по реформированию перинатальной службы.

Во время работы 10-го юбилейного конгресса воздавались почести профрессорам Роберто

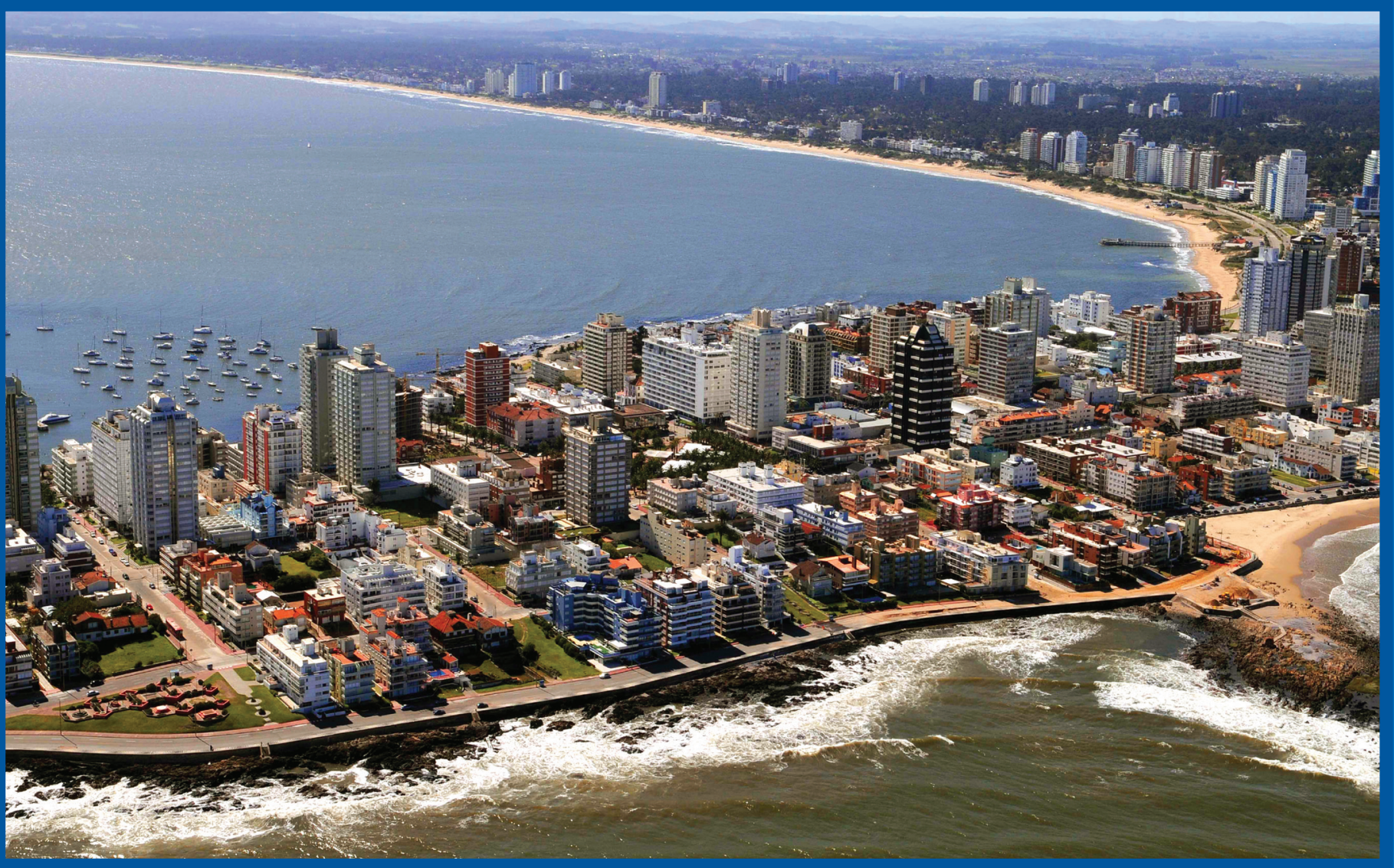

веке, имеют место три главные проблемы - преждевременные роды, преэклампсия и внутриутробное инфицирование, - для которых до сих пор не удалось разработать точных критериев ранней диагностики и профилактики. В этом направлении профессор Эрих Залинг (Германия) отметил, что исследования должны быть продолжены в двух основных направлениях: разработка простых скрининговых методик, которые можно бы применять в массовом порядке, и фундаментальные генетические (геном, протеомики) исследования для пациенток группы высокого риска по развитию этих осложнений.

Особое внимание было уделено профилактике родового травматизма: дистоции плечиков, слабости родовой деятельности, безосновательной эпизиотомии. Были даны рекомендации по снижению частоты рутинного выполнения эпизиотомии для перинатальных центров. В своем выступле-
Калдейро Барсия, Эриху Залингу (Erich Saling) и Казуо Маеда (Kazuo Maeda), которые считаются «отцами» перинатологии и объединяют три континента - Америку, Европу и Азию.

За выдающиеся успехи и многолетнюю активную деятельность в развитии перинатологии премией Эриха Залинга от Международной академии перинатальной медицины были награждены профессора акушер-гинеколог Асим Курияк (Аsiim Kurijak,Хорватия) и неонатолог Эдуардо Банкалари (Eduardo Bancalari, Чили, США).

$$
\text { *** }
$$

Ю.В. Давыдова выражает искреннюю благодарность компании «ГлаксоСмитКляйн», а также почетному консулу Восточной Республики Уругвай в Украине за всестороннюю поддержку и оказание помощи по участию в 10-м Всемирном конгрессе по перинатальной медицине. 